\title{
Hydromorphone for neuropathic pain in adults (Review)
}

Stannard C, Gaskell H, Derry S, Aldington D, Cole P, Cooper TE, Knaggs R, Wiffen PJ, Moore RA

Stannard C, Gaskell H, Derry S, Aldington D, Cole P, Cooper TE, Knaggs R, Wiffen PJ, Moore RA.

Hydromorphone for neuropathic pain in adults.

Cochrane Database of Systematic Reviews 2016, Issue 5. Art. No.: CD011604.

DOI: 10.1002/14651858.CD011604.pub2.

www.cochranelibrary.com 
HEADER 1

ABSTRACT

PLAIN LANGUAGE SUMMARY

SUMMARY OF FINDINGS

BACKGROUND

OBJECTIVES

METHODS

Figure 1.

RESULTS

Figure 2.

DISCUSSION

AUTHORS' CONCLUSIONS

ACKNOWLEDGEMENTS

REFERENCES

CHARACTERISTICS OF STUDIES

APPENDICES

WHAT'S NEW

HISTORY

CONTRIBUTIONS OF AUTHORS

DECLARATIONS OF INTEREST

SOURCES OF SUPPORT

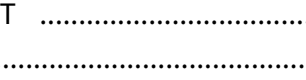

DIFFERENCES BETWEEN PROTOCOL AND REVIEW

NOTES

INDEX TERMS

\section{TABLE OF CONTENTS}


[Intervention Review]

\section{Hydromorphone for neuropathic pain in adults}

Cathy Stannard ${ }^{1}$, Helen Gaskell ${ }^{2}$, Sheena Derry², Dominic Aldington ${ }^{3}$, Peter Cole ${ }^{4}$, Tess E Cooper 5 , Roger Knaggs 6 , Philip J Wiffen², R Andrew Moore2

1NHS Gloucestershire CCG, Brockworth, UK. 2Pain Research and Nuffield Department of Clinical Neurosciences (Nuffield Division of Anaesthetics), University of Oxford, Oxford, UK. ${ }^{3}$ Royal Hampshire County Hospital, Winchester, UK. ${ }^{4}$ Oxford Pain Relief Unit, Churchill Hospital, Oxford University Hospitals NHS Trust, Oxford, UK. ${ }^{5}$ Cochrane Pain, Palliative and Supportive Care Group, Pain Research Unit, Churchill Hospital, Oxford, UK. ${ }^{6}$ School of Pharmacy, University of Nottingham, Nottingham, UK

Contact address: Dominic Aldington, Royal Hampshire County Hospital, Winchester, SO22 5DG, UK. daldington@me.com.

Editorial group: Cochrane Pain, Palliative and Supportive Care Group.

Publication status and date: Stable (no update expected for reasons given in 'What's new'), published in Issue 2, 2018.

Citation: Stannard C, Gaskell H, Derry S, Aldington D, Cole P, Cooper TE, Knaggs R, Wiffen PJ, Moore RA. Hydromorphone for neuropathic pain in adults. Cochrane Database of Systematic Reviews 2016, Issue 5. Art. No.: CD011604. DOI: 10.1002/14651858.CD011604.pub2.

Copyright @ 2018 The Cochrane Collaboration. Published by John Wiley \& Sons, Ltd.

\section{A B S T R A C T}

\section{Background}

Opioid drugs, including hydromorphone, are commonly used to treat neuropathic pain, and are considered effective by some professionals. Most reviews have examined all opioids together. This review sought evidence specifically for hydromorphone, at any dose, and by any route of administration. Other opioids are considered in separate reviews.

This review is part of an update of a previous review, Hydromorphone for acute and chronic pain that was withdrawn in 2013 because it needed updating and splitting to be more specific for different pain conditions. This review focuses only on neuropathic pain.

\section{Objectives}

To assess the analgesic efficacy of hydromorphone for chronic neuropathic pain in adults, and the adverse events associated with its use in clinical trials.

\section{Search methods}

We searched the Cochrane Central Register of Controlled Trials (CENTRAL), via the CRSO; MEDLINE via Ovid; and EMBASE via Ovid from inception to 17 November 2015, together with reference lists of retrieved papers and reviews, and two online study registries.

\section{Selection criteria}

We included randomised, double-blind studies of two weeks' duration or longer, comparing hydromorphone (at any dose, by any route of administration, or in any formulation) with placebo or another active treatment in chronic neuropathic pain.

\section{Data collection and analysis}

Two review authors independently searched for studies, extracted efficacy and adverse event data, and examined issues of study quality. We did not carry out any pooled analyses. We assessed the quality of the evidence using GRADE (Grading of Recommendations Assessment, Development and Evaluation).

\section{Main results}

Searches identified seven publications relating to four studies. We excluded three studies. One post hoc (secondary) analysis of a study published in four reports assessed the efficacy of hydromorphone in neuropathic pain, satisfied our inclusion criteria, and was included in the review. The single included study had an enriched enrolment, randomised withdrawal design with 94 participants who were successfully switched from oral morphine to oral hydromorphone extended release (about $60 \%$ of those enrolled). These participants were 
then randomised to continuing hydromorphone for 12 weeks or tapering down the hydromorphone dose to placebo. The methodological quality of the study was generally good, but we judged the risk of bias for incomplete outcome data as unclear, and for study size as high.

Since we identified only one study for inclusion, we were unable to carry out any analyses. The included study did not report any of our prespecified primary outcomes, which relate to the number of participants achieving moderate or substantial levels of pain relief. It did report a slightly larger increase in average pain intensity for placebo in the randomised withdrawal phase than for continuing with hydromorphone. It also reported the number of participants who withdrew due to lack of efficacy in the randomised withdrawal phase, which may be an indicator of efficacy. However, in addition to using an enriched enrolment, randomised withdrawal study design, there was an unusual choice of imputation methods for withdrawals (about $50 \%$ of participants); the evidence was of very low quality and inadequate to make a judgement on efficacy. Adverse events occurred in about half of participants with hydromorphone, the most common being constipation and nausea. A similar proportion of participants experienced adverse events with placebo, the most common being opioid withdrawal syndrome (very low quality evidence). Most adverse events were mild or moderate in intensity. One in eight participants withdrew while taking hydromorphone during the conversion and titration phase, despite participants being opioid-tolerant (very low quality evidence).

We downgraded the quality of the evidence to very low because there was only one study with few participants, it did not report clinically useful efficacy outcomes, and it was a post hoc analysis.

\section{Authors' conclusions}

There was insufficient evidence to support or refute the suggestion that hydromorphone has any efficacy in any neuropathic pain condition.

\section{PLAIN LANGUAGE SUMMARY}

\section{Hydromorphone for neuropathic pain in adults}

\section{Bottom line}

There is no good evidence to support or refute the suggestion that hydromorphone works in any neuropathic pain condition.

\section{Background}

Neuropathic pain is pain coming from damaged nerves. It is different from pain messages that are carried along healthy nerves from damaged tissue (for example, a fall or cut, or arthritic knee). Neuropathic pain is often treated by different medicines (drugs) to those used for pain from damaged tissue, which we often think of as painkillers. Medicines that are sometimes used to treat depression or epilepsy can be very effective in some people with neuropathic pain. But sometimes opioid painkillers are used to treat neuropathic pain.

Opioid painkillers are drugs like morphine. Morphine is derived from plants, but many opioids are also made by chemical synthesis rather than being extracted from plants. Hydromorphone is one of these synthetic opioids. It is available in numerous countries for use as a painkiller, and can be given by mouth or by injection.

This review is part of an update of a previous review, Hydromorphone for acute and chronic pain that was withdrawn in 2013 because it needed updating and splitting to be more specific for different pain conditions. This review focuses only on neuropathic pain.

\section{Study characteristics}

In November 2015, we searched for clinical trials where hydromorphone was used to treat neuropathic pain in adults. We found one small study that did this and met our requirements for the review. The study had a complicated design. Only a minority of participants had neuropathic pain, with only 94 in the comparison with placebo. Important pain outcomes were not reported.

\section{Key results}

The study provided no convincing evidence of any benefit for hydromorphone over placebo. Of those people who started taking hydromorphone, one in eight stopped because of side effects in the first part of the study. The most common side effects were constipation and nausea, which are typically experienced with opioids.

\section{Quality of the evidence}

We rated the quality of the evidence as very low because of the study design, poor reporting of important outcomes, and small numbers of participants. Very low quality evidence means that we are very uncertain about the results. 


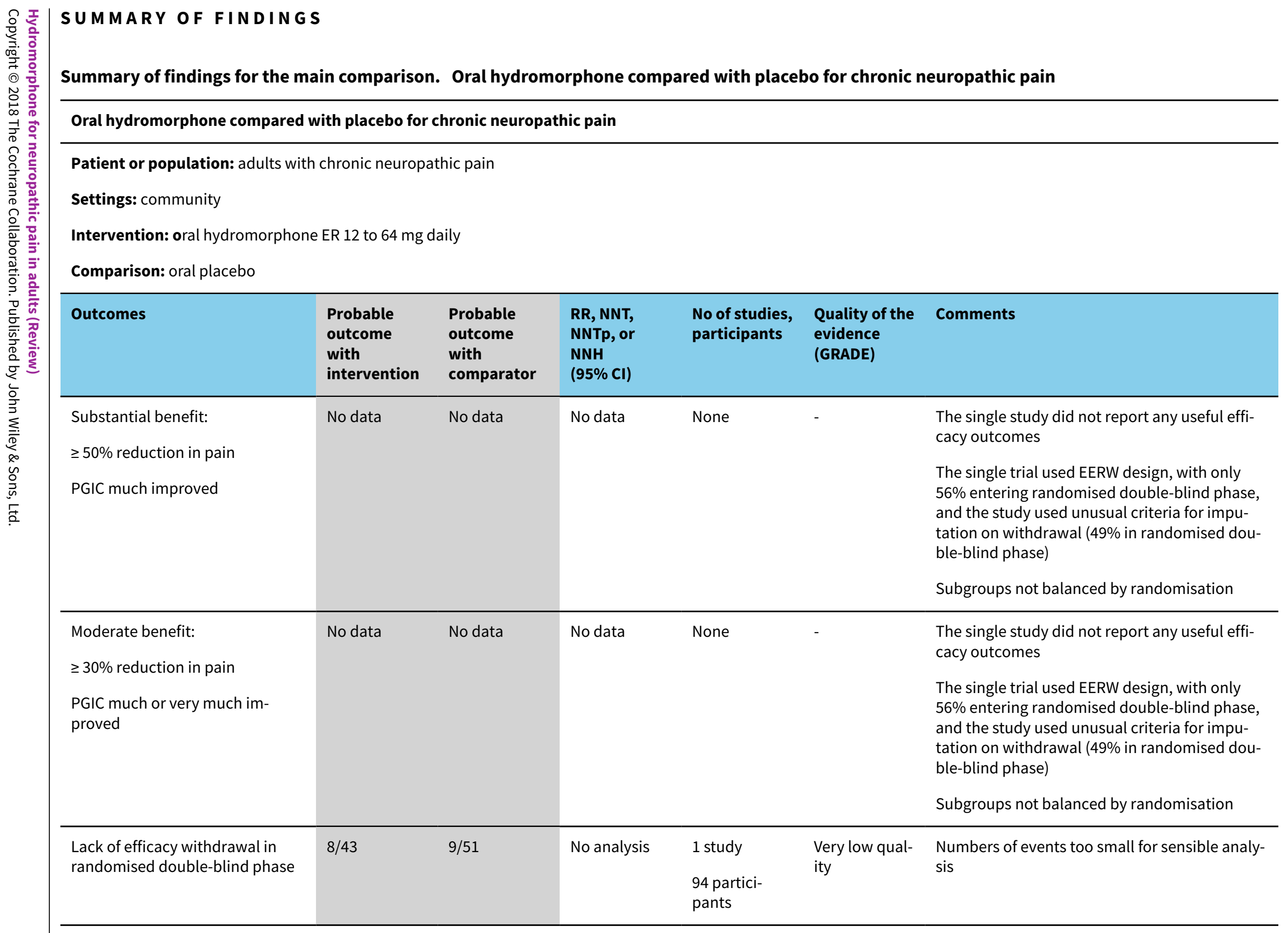




\begin{tabular}{|c|c|c|c|c|c|c|}
\hline \multicolumn{2}{|r|}{$\begin{array}{l}\text { Adverse event withdrawal in ran- } \\
\text { domised double-blind phase }\end{array}$} & $0 / 51$ & No analysis & $\begin{array}{l}1 \text { study } \\
94 \text { partici- } \\
\text { pants }\end{array}$ & $\begin{array}{l}\text { Very low qual- } \\
\text { ity }\end{array}$ & $\begin{array}{l}\text { Numbers of events too small for sensible analy- } \\
\text { sis }\end{array}$ \\
\hline 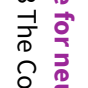 & Serious adverse events & $\begin{array}{l}\text { None reported specifically for } \\
\text { neuropathic pain }\end{array}$ & - & - & - & - \\
\hline 愛 & Deaths & None reported & - & - & - & - \\
\hline 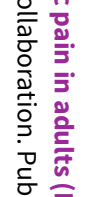 & \multicolumn{6}{|c|}{$\begin{array}{l}\text { GRADE Working Group grades of evidence } \\
\text { High quality: Further research is very unlikely to change our confidence in the estimate of effect. } \\
\text { Moderate quality: Further research is likely to have an important impact on our confidence in the estimate of effect and may change the estimate. } \\
\text { Low quality: Further research is very likely to have an important impact on our confidence in the estimate of effect and is likely to change the estimate. } \\
\text { Very low quality: We are very uncertain about the estimate. }\end{array}$} \\
\hline
\end{tabular}

Cl: confidence interval; EERW: enriched enrolment, randomised withdrawal; ER: extended release; NNT: number needed to treat for an additional beneficial outcome; NNH: number needed to treat for an additional harmful outcome; NNTp: number needed to treat to prevent an additional outcome; PGIC: Patient Global Impression of Change. 


\section{B A C K G R O U N D}

This review is based on a template for reviews of drugs used to relieve neuropathic pain. The aim is for all reviews to use the same methods, based on new criteria for what constitutes reliable evidence in chronic pain (Moore 2010a; Appendix 1).

The review forms part of an update of a previous review, Hydromorphone for acute and chronic pain (Quigley 2013), which was withdrawn in 2013 because of a need to update, and to split the title to be more specific for different pain conditions. This review focuses only on neuropathic pain. A protocol for Hydromorphone for cancer pain has already been published (Bao 2014).

\section{Description of the condition}

The 2011 International Association for the Study of Pain definition of neuropathic pain is "pain caused by a lesion or disease of the somatosensory system" (Jensen 2011), and based on a definition agreed at an earlier consensus meeting (Treede 2008). Neuropathic pain is a consequence of a pathological maladaptive response of the nervous system to 'damage' from a wide variety of potential causes. It is characterised by pain in the absence of a noxious stimulus and may be spontaneous (continuous or paroxysmal) in its temporal characteristics or be evoked by sensory stimuli (dynamic mechanical allodynia where pain is evoked by light touch of the skin). Neuropathic pain is associated with a variety of sensory loss (numbness) and sensory gain (allodynia) clinical phenomena, the exact pattern of which vary between patient and disease, perhaps reflecting different pain mechanisms operating in an individual patient and therefore potentially predictive of response to treatment (Demant 2014; Helfert 2015; von Hehn 2012). Pre-clinical research hypothesises a bewildering array of possible pain mechanisms that may operate in people with neuropathic pain, which largely reflect pathophysiological responses in both the central and peripheral nervous systems, including neuronal interactions with immune cells (Baron 2012; Calvo 2012; von Hehn 2012). Overall, the treatment gains in neuropathic pain, to even the most effective of available drugs, are modest (Finnerup 2015; Moore 2013a), and a robust classification of neuropathic pain is not yet available (Finnerup 2013).

Neuropathic pain is usually divided according to the cause of nerve injury. There may be many causes, but some common causes of neuropathic pain include diabetes (painful diabetic neuropathy $(\mathrm{PDN})$ ), shingles (postherpetic neuralgia (PHN)), amputation (stump and phantom limb pain), neuropathic pain after surgery or trauma, stroke or spinal cord injury, trigeminal neuralgia, and human immunodeficiency virus (HIV) infection. Sometimes the cause is not known.

Many people with neuropathic pain conditions are significantly disabled with moderate or severe pain for many years. Chronic pain conditions comprised 5 of the 11 top-ranking conditions for years lived with disability in 2010 (Vos 2012), and are responsible for considerable loss of quality of life and employment, and increased healthcare costs (Moore 2014a).

In systematic reviews, the overall prevalence of neuropathic pain in the general population is reported to be between $7 \%$ and $10 \%$ (van Hecke 2014), and about $7 \%$ in a systematic review of studies published since 2000 (Moore 2014a). In individual countries, prevalence rates have been reported as 3.3\% in Austria (Gustorff
2008), 6.9\% in France (Bouhassira 2008), and up to $8 \%$ in the UK (Torrance 2006). Some forms of neuropathic pain, such as PDN and postsurgical chronic pain (which is often neuropathic in origin), are increasing (Hall 2008). The prevalence of PHN is likely to fall if vaccination against the herpes virus becomes widespread.

Estimates of incidence vary between individual studies for particular origins of neuropathic pain, often because of small numbers of cases. In primary care in the UK, between 2002 and 2005 , the incidences (per 100,000 person-years' observation) were 28 (95\% confidence interval ( $\mathrm{Cl}) 27$ to 30 ) for PHN, 27 (26 to 29) for trigeminal neuralgia, 0.8 (0.6 to 1.1 ) for phantom limb pain, and 21 (20 to 22) for PDN (Hall 2008). Other researchers have estimated an incidence of 4 in 100,000 per year for trigeminal neuralgia (Katusic 1991; Rappaport 1994), and of 12.6 per 100,000 personyears for trigeminal neuralgia and 3.9 per 100,000 person-years for PHN in a study of facial pain in the Netherlands (Koopman 2009). One systematic review of chronic pain demonstrated that some neuropathic pain conditions, such as PDN, are much more common than others, with prevalence rates up to 400 per 100,000 personyears (McQuay 2007).

Neuropathic pain is difficult to treat effectively, with only a minority of people experiencing a clinically relevant benefit from any one intervention. A multidisciplinary approach is now advocated, combining pharmacological interventions with physical or cognitive (or both) interventions. Conventional analgesics such as paracetamol and nonsteroidal anti-inflammatory drugs are not thought to be effective, but without evidence to support or refute that view. Some people may derive some benefit from a topical lidocaine patch or low-concentration topical capsaicin, although evidence about benefits is uncertain (Derry 2012; Derry 2014). Highconcentration topical capsaicin may benefit some people with PHN (Derry 2013). Treatment is often by so-called 'unconventional analgesics' (pain modulators) such as antidepressants (duloxetine and amitriptyline; Lunn 2014; Moore 2012a; Sultan 2008), or antiepileptics (gabapentin or pregabalin; Moore 2009; Moore 2014b; Wiffen 2013).

The proportion of people who achieve worthwhile pain relief (typically at least 50\% pain intensity reduction; Moore 2013b) is small, generally only $10 \%$ to $25 \%$ more than with placebo, with numbers needed to treat for an additional beneficial outcome (NNT) usually between 4 and 10 (Kalso 2013; Moore 2013a). Neuropathic pain is not particularly different from other chronic pain conditions in that only a small proportion of trial participants have a good response to treatment (Moore 2013a).

The current National Institute for Health and Care Excellence (NICE) guidance for the pharmacological management of neuropathic pain suggests offering a choice of amitriptyline, duloxetine, gabapentin, or pregabalin as initial treatment for neuropathic pain (with the exception of trigeminal neuralgia), with switching if the first, second, or third drugs tried are not effective or not tolerated (NICE 2013). This concurs with other recent guidance (Finnerup 2015).

\section{Description of the intervention}

Hydromorphone (also known as dihydromorphinone) is a semisynthetic derivative of morphine. It is marketed in various countries under various brand names, commonly known as Dilaudid, but with other names used in different countries around the 
world (including Hydal, Dimorphone, Sophidone LP, Hydrostat, Hydromorfan, Hydromorphan, Hymorphan, Laudicon, Opidol, Palladone, Hydromorph Contin). Since its clinical introduction in 1926, it has been used as an alternative opioid analgesic to morphine, as it has a similar chemical structure but is more water soluble (Urquhart 1988) and potent (Twycross 1994).

A range of issues relate to the use of hydromorphone in chronic pain, including formulation, metabolism, potency compared with other opioids, and risk of misuse (Gregory 2013). Most hydromorphone use has been for cancer pain, where advantages include a range of possible routes of administration, together with an absence of active metabolites, differentiating hydromorphone from morphine. Hydromorphone is itself an important metabolite of hydrocodone.

Hydromorphone can be administered through oral (immediateand controlled-release formulations), intravenous, subcutaneous, epidural, intrathecal, and other routes (Murray 2005). The high aqueous solubility of hydromorphone is considered by some healthcare professionals to be beneficial for people who are resistant to opioids and require higher doses in cancer pain, often administered by intrathecal pumps (Portenoy 2011). Hydromorphone as OROS ${ }^{\circledR}$ hydromorphone extended-release (ER) is five times more potent than morphine (Binsfeld 2010; Sarhill 2001). This allows a smaller milligram dose of hydromorphone to be used for an equianalgesic effect.

\section{How the intervention might work}

Opioids such as hydromorphone bind to specific opioid receptors in the nervous system and other tissues; there are three principal classes of receptors (mu, kappa, and delta) though others have been suggested, and subtypes of receptors are considered to exist. Binding of opioid agonists such as hydromorphone to receptors brings about complex cellular changes, outcomes of which include decreased perception of pain, decreased reaction to pain, and increased pain tolerance. Opioids from plant sources have been used for thousands of years to treat pain.

\section{Why it is important to do this review}

One UK survey found that weak and strong opioids were used frequently for treating neuropathic pain (Hall 2013). Hydromorphone is nowadays rarely prescribed. In the past, it was prescribed either as the opioid of choice when morphine or other opioids could not be tolerated, or when a higher dose of opioid was required. Since the early 2000s, a marked increase in prescribing of opioids for non-cancer pain in general, despite a relatively modest evidence base, has in some countries led to widespread diversion with consequent abuse, misuse, and mortality. Concurrently, suspicion has arisen that opioid-induced hyperalgesia, together with tolerance to the analgesic effects of opioids, may in reality result in a lesser degree of benefit for opioids in neuropathic pain than previously assumed.

The standards used to assess evidence in chronic pain trials have changed substantially in recent years, with particular attention being paid to trial duration, withdrawals, and statistical imputation following withdrawal, all of which can substantially alter estimates of efficacy. The most important change is the move from using mean pain scores, or mean change in pain scores, to the number of people who have a large decrease in pain (by at least $50 \%$ ) and who continue in treatment, ideally in trials of eight to 12 weeks' duration or longer. Pain intensity reduction of $50 \%$ or more correlates with improvements in co-morbid symptoms, function, and quality of life. These standards are set out in the PaPaS Author and Referee Guidance for pain studies of the Cochrane Pain, Palliative and Supportive Care Group (PaPaS 2012).

This Cochrane review assessed evidence using methods that make both statistical and clinical sense, using developing criteria for what constitutes reliable evidence in chronic pain (Moore 2010a). Trials included and analysed met a minimum of reporting quality (blinding, randomisation), validity (duration, dose and timing, diagnosis, outcomes, etc), and size (ideally at least 500 participants in a comparison in which the NNT is 4 or above; Moore 1998). This approach sets high standards for the demonstration of efficacy and marks a departure from how reviews were conducted previously.

Taking this newer, more rigorous approach is particularly important for opioids in chronic non-cancer pain. Opioids in clinical trials on non-cancer pain are associated with very high withdrawal rates of up to $60 \%$ over about 12 weeks (Moore 2010b). Many withdrawals occur within the first few weeks, when participants experience pain relief but cannot tolerate the drug. The common practice of using the last observed results carried forward to the end of the trial many weeks later (last observation carried forward (LOCF)) can, therefore, produce results based largely on participants no longer in the trial, and who in the real world could not achieve pain relief because they could not take the drug. The newer standards, outlined in Appendix 1, would not allow this and can produce very different results. For example, one large analysis of pooled data from trials in osteoarthritis and chronic low back pain conducted over about 12 weeks judged oxycodone effective, but an analysis of the same data using the new clinically meaningful standards showed it to be significantly worse than placebo (Lange 2010).

One previous Cochrane review demonstrated the limitations of our knowledge about opioids in neuropathic pain, except in short duration studies of 24 hours or less (McNicol 2013). These limitations were confirmed by a review specific to oxycodone (Gaskell 2014). A review specific to hydromorphone is timely.

\section{O B JECTIVES}

To assess the analgesic efficacy of hydromorphone for chronic neuropathic pain in adults, and the adverse events associated with its use in clinical trials.

\section{METHODS}

\section{Criteria for considering studies for this review}

\section{Types of studies}

We included randomised controlled trials (RCTs) with doubleblind assessment of participant outcomes following two weeks or more of treatment, although the emphasis of the review was on studies with a duration of eight weeks or longer. We required full journal publication, with the exception of online clinical trial results summaries of otherwise unpublished clinical trials and abstracts with sufficient data for analysis. We did not include short abstracts (usually meeting reports), or studies that were nonrandomised, studies of experimental pain, case reports, and clinical observations. 


\section{Types of participants}

Studies included adults aged 18 years and above with one or more chronic neuropathic pain conditions including (but not limited to):

1. cancer-related neuropathy;

2. central neuropathic pain;

3. complex regional pain syndrome (CRPS) Type II;

4. human immunodeficiency virus (HIV) neuropathy;

5. painful diabetic neuropathy (PDN);

6. phantom limb pain;

7. postherpetic neuralgia (PHN);

8. postoperative or traumatic neuropathic pain;

9. spinal cord injury; and

10.trigeminal neuralgia.

If studies included participants with more than one type of neuropathic pain, we planned to analyse results according to the primary condition.

\section{Types of interventions}

Hydromorphone at any dose, by any route, administered for the relief of neuropathic pain and compared with placebo or any active comparator.

\section{Types of outcome measures}

We anticipated that studies would use a variety of outcome measures, with most studies using standard subjective scales (numerical rating scale (NRS) or visual analogue scale (VAS)) for pain intensity or pain relief, or both. We were particularly interested in Initiative on Methods, Measurement, and Pain Assessment in Clinical Trials (IMMPACT) definitions for moderate and substantial benefit in chronic pain studies (Dworkin 2008). These are defined as:

1. at least $30 \%$ pain relief over baseline (moderate);

2. at least $50 \%$ pain relief over baseline (substantial);

3. much or very much improved on Patient Global Impression of Change scale (PGIC; moderate);

4. very much improved on PGIC (substantial).

These outcomes are different from those used in most earlier reviews, concentrating as they do on dichotomous outcomes where pain responses do not follow a normal (Gaussian) distribution. People with chronic pain desire high levels of pain relief, ideally more than $50 \%$ pain intensity reduction, and ideally having no worse than mild pain (Moore 2013b; O'Brien 2010).

\section{Primary outcomes}

1. Participant-reported pain relief of $30 \%$ or greater.

2. Participant-reported pain relief of $50 \%$ or greater.

3. PGIC much or very much improved.

4. PGIC very much improved.

\section{Secondary outcomes}

1. Any pain-related outcome indicating some improvement.

2. Withdrawals due to lack of efficacy, adverse events, and for any cause.

3. Participants experiencing any adverse event.

4. Participants experiencing any serious adverse event. Serious adverse events typically include any untoward medical occurrence or effect that at any dose results in death, is lifethreatening, requires hospitalisation or prolongation of existing hospitalisation, results in persistent or significant disability or incapacity, is a congenital anomaly or birth defect, is an 'important medical event' that may jeopardise the person, or may require an intervention to prevent one of the above characteristics or consequences.

5. Specific adverse events, particularly somnolence and dizziness.

\section{Search methods for identification of studies}

\section{Electronic searches}

We searched the following databases, without language restrictions.

1. Cochrane Central Register of Controlled Trials (CENTRAL, via the Cochrane Register of Studies Online database (CRSO)) on 17 November 2015

2. MEDLINE (via Ovid), 1946 to 17 November 2015.

3. EMBASE (via Ovid), 1974 to 17 November 2015.

Search strategies for CENTRAL, MEDLINE, and EMBASE are in Appendix 2, Appendix 3, and Appendix 4, respectively.

\section{Searching other resources}

We reviewed the bibliographies of any RCTs identified and review articles, and searched clinical trial databases (ClinicalTrials.gov (ClinicalTrials.gov) and the World Health Organization International Clinical Trials Registry Platform (ICTRP) (apps.who.int/trialsearch/)) to identify additional published or unpublished data. We did not contact investigators or study sponsors.

\section{Data collection and analysis}

We planned to perform separate analyses according to particular neuropathic pain conditions, and would combine different neuropathic pain conditions in analyses for exploratory purposes only. In the event, we included only one study, in people with chronic low back pain with a neuropathic component.

\section{Selection of studies}

We determined eligibility by first reading the abstract of each study identified by the search. We eliminated studies that clearly did not satisfy the inclusion criteria, and we obtained full copies of the remaining studies. Two review authors made the decisions. Two review authors read these studies independently and reached agreement by discussion. We did not anonymise the studies in any way before assessment. We provided a PRISMA flow chart (Figure 1). 
Figure 1. Study flow diagram.

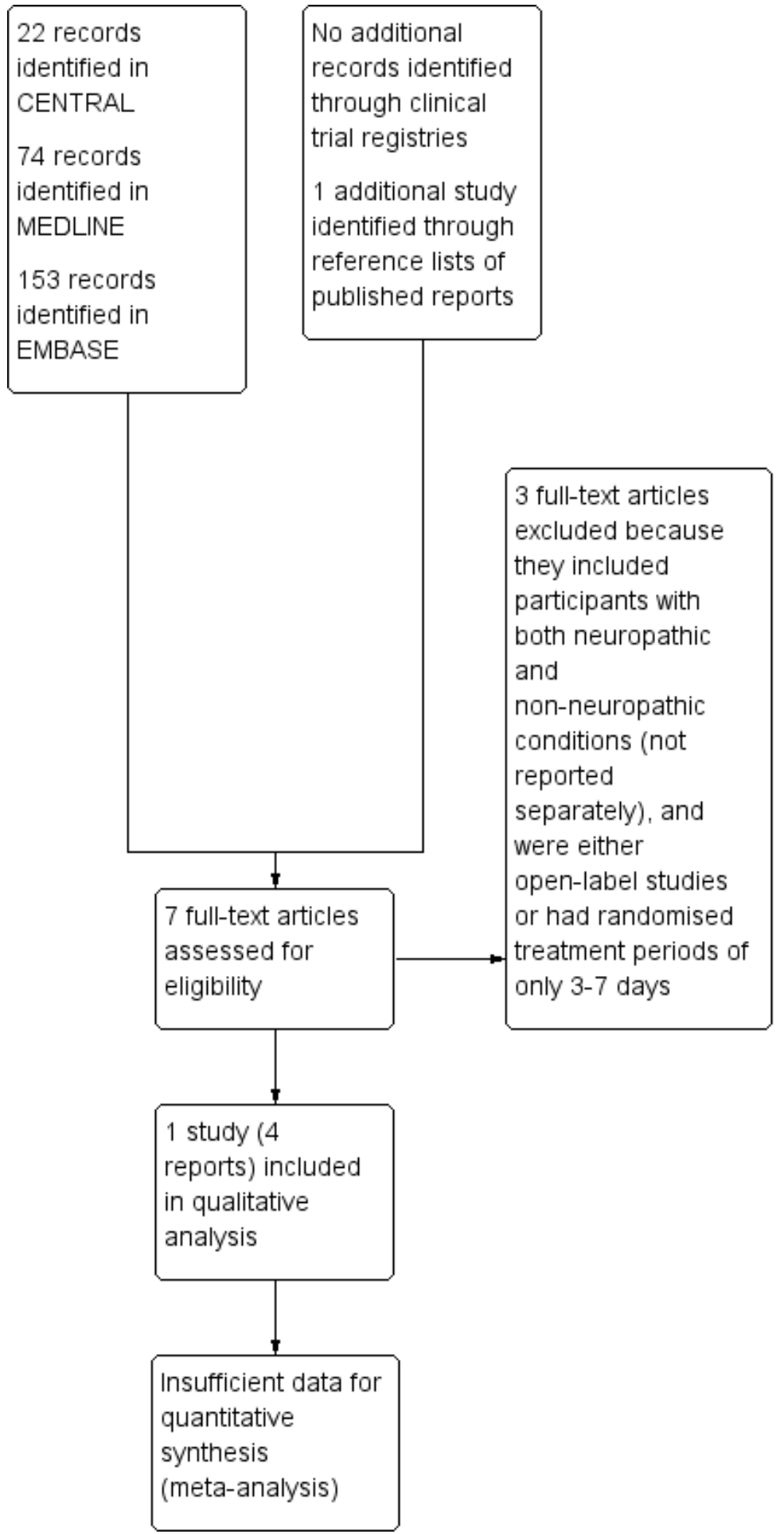

\section{Data extraction and management}

Two review authors extracted data independently using a standard form and checked for agreement before entry into Review Manager 5 (RevMan 2014), or any other analysis tool. We included information about the pain condition and number of participants treated, drug and dosing regimen, study design (placebo or active control), study duration and follow-up, analgesic outcome measures and results, withdrawals, and adverse events (participants experiencing any adverse event or serious adverse event). 


\section{Assessment of risk of bias in included studies}

We used the Oxford Quality Score as the basis for inclusion (Jadad 1996), limiting inclusion to studies that were randomised and double-blind as a minimum.

Two review authors independently assessed the risk of bias for each study, using the criteria outlined in the Cochrane Handbook for Systematic Reviews of Interventions (Higgins 2011), and adapted from those used by the Cochrane Pregnancy and Childbirth Group, with any disagreements resolved by discussion. We assessed the following for each study.

1. Random sequence generation (checking for possible selection bias). We assessed the method used to generate the allocation sequence as: low risk of bias (any truly random process, eg random number table; computer random number generator); unclear risk of bias (when the method used to generate the sequence was not clearly stated). We excluded studies at a high risk of bias that used a non-random process (eg odd or even date of birth; hospital or clinic record number).

2. Allocation concealment (checking for possible selection bias). The method used to conceal allocation to interventions prior to assignment determines whether intervention allocation could have been foreseen in advance of, or during, recruitment, or changed after assignment. We assessed the methods as: low risk of bias (eg telephone or central randomisation; consecutively numbered, sealed, opaque envelopes); unclear risk of bias (when the method was not clearly stated). We excluded studies that did not conceal allocation and were therefore at a high risk of bias (eg open list).

3. Blinding of outcome assessment (checking for possible detection bias). We assessed the methods used to blind study participants and outcome assessors from knowledge of which intervention a participant received. We assessed the methods as: low risk of bias (study stated that it was blinded and described the method used to achieve blinding, eg identical tablets, matched in appearance and smell); unclear risk of bias (study stated that it was blinded but did not provide an adequate description of how it was achieved). We excluded studies at a high risk of bias that were not double-blind.

4. Incomplete outcome data (checking for possible attrition bias due to the amount, nature, and handling of incomplete outcome data). We assessed the methods used to deal with incomplete data as: low risk of bias (fewer than $10 \%$ of participants did not complete the study or used 'baseline observation carried forward' analysis, or both); unclear risk of bias (used LOCF analysis); or high risk of bias (used 'completer' analysis).

5. Size of study (checking for possible biases confounded by small size). We assessed studies as being at low risk of bias (200 participants or more per treatment arm); unclear risk of bias (50 to 199 participants per treatment arm); or high risk of bias (fewer than 50 participants per treatment arm).

\section{Measures of treatment effect}

We planned to calculate NNTs as the reciprocal of the absolute risk reduction (ARR; McQuay 1998). For unwanted effects, the NNT becomes the number needed to treat for an additional harmful outcome (NNH) and is calculated in the same manner. We planned to use dichotomous data to calculate risk ratio (RR) with $95 \%$ confidence intervals $(\mathrm{Cl})$ using a fixed-effect model unless we found significant statistical heterogeneity (see below). We did not plan to use continuous data in analyses.

\section{Unit of analysis issues}

We planned to split the control treatment arm between active treatment arms in a single study if there was more than one active treatment arm, and they were not combined for analysis.

\section{Dealing with missing data}

We extracted data using intention-to-treat (ITT) analysis where the ITT population consisted of participants who were randomised, took at least one dose of the assigned study medication, and provided at least one postbaseline assessment. We assigned zero improvement to missing participants wherever possible.

\section{Assessment of heterogeneity}

We planned to deal with clinical heterogeneity by combining studies that examined similar conditions, and assess statistical heterogeneity visually (L'Abbé 1987), and with the use of the 12 statistic. If the $1^{2}$ value was greater than $50 \%$, we planned to consider possible reasons for this. In the event, there was only one included study, so heterogeneity was not an issue.

\section{Assessment of reporting biases}

The aim of this review was to use dichotomous outcomes of known utility and of value to people with pain (Hoffman 2010; Moore 2010c; Moore 2010d; Moore 2010e; Moore 2013b). The review did not depend on what the authors of the original studies chose to report or not, though clearly difficulties arose because the included study did not report any dichotomous efficacy results. Therefore, we extracted mean data, which probably reflect efficacy and utility poorly, as a secondary outcome that could give some indication of efficacy.

We planned to assess publication bias using a method designed to detect the amount of unpublished data with a null effect required to make any result clinically irrelevant (usually taken to mean an NNT of 10 or higher; Moore 2008). In the event, this was not possible.

\section{Data synthesis}

We planned to use a fixed-effect model for meta-analysis, or a random-effects model if there was significant clinical heterogeneity and it was considered appropriate to combine studies.

We planned to analyse data for each painful condition in three tiers, according to outcome and freedom from known sources of bias.

1. The first tier would use data meeting current best standards, where studies reported the outcome of at least $50 \%$ pain intensity reduction over baseline (or its equivalent), without the use of LOCF or other imputation method for drop-outs, reported an ITT analysis, lasted eight or more weeks, had a parallel-group design, and had at least 200 participants (preferably at least 400) in the comparison (Moore 1998; Moore 2010a; Moore 2012a; Moore 2012b).

2. The second tier would use data from at least 200 participants but where one or more of the first-tier conditions above was not met (eg reporting at least $30 \%$ pain intensity reduction, using LOCF or a completer analysis, or lasting four to eight weeks). 
3. The third tier of evidence would relate to data from fewer than 200 participants, or where there were expected to be significant problems because, for example, of very short duration studies of less than four weeks; where there was major heterogeneity between studies; or where there were shortcomings in allocation concealment, attrition, or incomplete outcome data. For this third tier of evidence, no data synthesis is reasonable and may be misleading, but an indication of beneficial effects might be possible.

\section{Quality of the evidence}

Two review authors independently rated the quality of each outcome. We used the GRADE (Grades of Recommendation, Assessment, Development and Evaluation) system to assess the quality of the evidence related to the key outcomes listed in Types of outcome measures, as appropriate (Appendix 5; Chapter 12, Higgins 2011).

\section{'Summary of findings' table}

We have included a 'Summary of findings' table as set out in the author guide ( $\mathrm{PaPaS}$ 2012). We have included the planned outcomes of at least $50 \%$ pain intensity reduction and PGIC very much improved (substantial benefit), at least 30\% pain intensity reduction and PGIC much or very much improved (moderate benefit), withdrawals due to adverse events, serious adverse events, and death. In addition, we have included 'lack of efficacy withdrawal in randomised double-blind phase', since this may be a relevant indicator of efficacy for this study design.

\section{Subgroup analysis and investigation of heterogeneity}

We planned all analyses to be according to individual neuropathic pain conditions, because placebo response rates for the same outcome can vary between conditions, as can the drug-specific effects (Moore 2009).

We did not plan subgroup analyses since experience of previous reviews indicated that there would be too few data for any meaningful subgroup analysis (Gaskell 2014; McNicol 2013).

\section{Sensitivity analysis}

We did not plan specific sensitivity analysis because the evidence base is known to be too small to allow reliable analysis. We had hoped to examine details of dose-escalation schedules to see if this could provide some basis for a sensitivity analysis.

\section{RE S U L T S}

\section{Description of studies}

\section{Results of the search}

Our searches identified 22 potentially relevant records in CENTRAL, 74 in MEDLINE, and 153 in EMBASE. We found one additional study by searching the reference lists of published articles, but no further studies in clinical trial registries. After reading the titles and abstracts, we obtained and read the full texts of seven records. We included one study (four records) and excluded three studies (Figure 1).

\section{Included studies}

We included one study, which was reported in four publications. Participants had moderate to severe chronic low back pain, and results for participants with a definite or probable neuropathic pain component were reported separately from participants with nonneuropathic or nociceptive pain in a post hoc analysis (Nalamachu 2014). The neuropathic component was determined using the Quebec Task Force Classification of Spinal Disorders (Classes 3 to 6; QTFSD 1987). This record was one of four publications between 2010 and 2014 reporting on the same clinical trial, but as best we can judge none was a duplicated report.

Participants were opioid-tolerant and taking stable doses of analgesics for at least two weeks before screening. The study had an open-label conversion and titration period lasting two to four weeks, followed by a randomised, double-blind, placebocontrolled withdrawal period of 12 weeks for participants who had a good response. These 'responders' took 12 to $64 \mathrm{mg}$ of hydromorphone ER daily at a stable dose for at least seven consecutive days, had a mean pain intensity of $4 / 10$ or less, required two or fewer doses of rescue medication per day, had no intolerable adverse events, and believed that the study medication had helped their pain.

Overall, the study included equal numbers of men and women with a mean age of 49 years and baseline pain intensity at screening of $6.4 / 10$, and at randomisation of 3.2/10. A minority of participants were classified as having neuropathic pain. In the whole trial, 443 participants were screened initially, and $167(38 \%)$ of them were considered to have neuropathic pain. Of the 167,73 (44\%) did not meet the criteria for entering the randomised, doubleblind comparison with placebo, and the final number entering the randomised double-blind comparison between hydromorphone and placebo was 94 (56\%).

The study was not randomised according to neuropathic pain status. While the numbers across groups appeared reasonably similar for most characteristics, the authors commented that the subgroups were not balanced.

\section{Excluded studies}

We excluded three studies because they recruited participants with various pain conditions and did not report results for neuropathic pain separately. In addition, one was open-label (Binsfeld 2010), and two had double-blind treatment periods of seven days or less (Grosset 2005; Jansen DO-119).

\section{Risk of bias in included studies}

A summary of the risk of bias assessment is available in Figure 2 . 
Figure 2. Risk of bias summary: review authors' judgements about each risk of bias item for each included study.

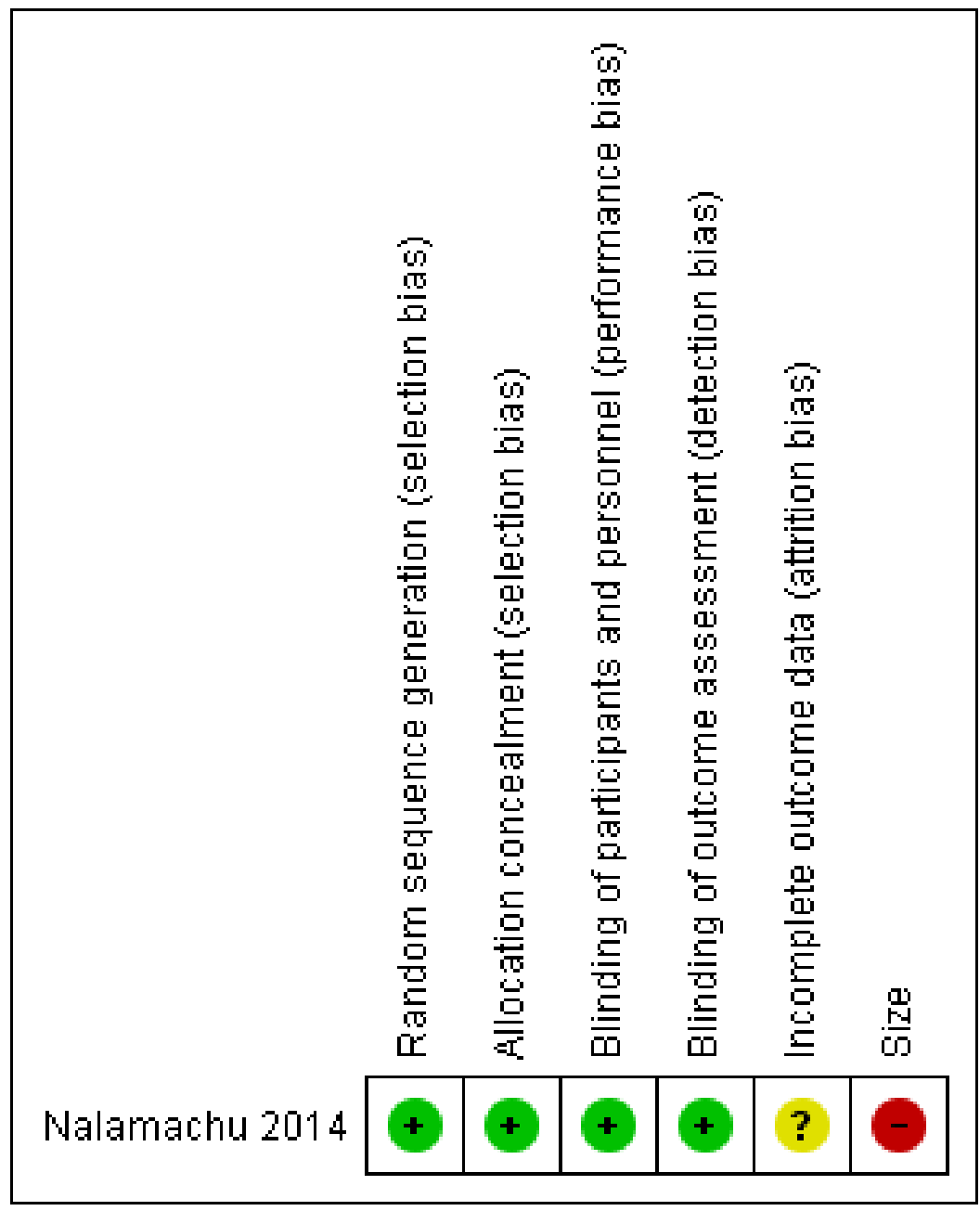

\section{Allocation}

The study was randomised for the double-blind withdrawal period and the method of randomisation and allocation concealment were described. We judged this study at low risk of bias for random sequence generation and allocation concealment.

\section{Blinding}

The study was blinded for the withdrawal period, and the method of blinding was described. Participants allocated to the placebo arm in this period had a tapered withdrawal of active treatment, which should help to maintain blinding. We judged this study at low risk of bias for performance and detection bias.

\section{Incomplete outcome data}

All participants were accounted for and imputation methods were described. Different imputation methods were used according to the reason for withdrawal. It is not immediately apparent that this was appropriate, especially as LOCF was used for lack of efficacy and other withdrawals not due to adverse events of opioid withdrawal symptoms. We judged this study at unclear risk of bias for attrition bias.

\section{Selective reporting}

We could not judge whether there was selective reporting as this was a post hoc analysis, presumably performed after the blind was broken, and was not the primary report of the study.

\section{Other potential sources of bias}

We judged the study to be at high risk of bias due to its size (43 participants in the hydromorphone arm and 51 participants in the placebo arm for the randomised phase).

\section{Effects of interventions}

See: Summary of findings for the main comparison Oral hydromorphone compared with placebo for chronic neuropathic pain

Since we identified only one study for inclusion, we were unable to carry out any analyses. We judged the quality of the evidence as very low, downgraded because there was only one study with few participants, it did not report clinically useful efficacy outcomes, and it was a post hoc analysis (Summary of findings for the main comparison). 


\section{Efficacy}

The included study used an enriched enrolment, randomised withdrawal (EERW) design, so did not report any of our prespecified efficacy outcomes. See Appendix 6 for summary of efficacy.

Of the 167 participants with neuropathic pain who entered the conversion and titration phase, 94 (56\%) were classified as 'responders' (see Included studies: adequate pain control, stable dose within predefined range, tolerable adverse events), and $44 \%$ withdrew. The mean pain intensity was reduced from $6.4 / 10$ to 3.2/10, and the mean Patient Global Assessment of treatment was reduced from 3.7 to 2.6 ( $1=$ excellent, $5=$ poor $)$.

Of the 43 participants with neuropathic pain randomised to continue with hydromorphone ER, 21 (49\%) withdrew during the double-blind withdrawal phase, compared with 30/51 (59\%) who were randomised to placebo. Withdrawal due to lack of efficacy in the double-blind withdrawal phase occurred in $8 / 43$ participants with hydromorphone ER and 9/51 with placebo. The mean increase in pain intensity during this period was $0.6 / 10$ with hydromorphone ER and 1.4/10 with placebo.

\section{Withdrawals}

See Appendix 7 for summary of withdrawals.

\section{Withdrawals due to lack of efficacy}

In the conversion and titration phase, 27/167 (16\%) participants withdrew due to lack of efficacy.

In the double-blind withdrawal phase, withdrawals due to lack of efficacy occurred in 8/43 participants with hydromorphone ER and 9/51 with placebo.

\section{Withdrawals due to adverse events}

In the conversion and titration phase, 20/167 (12\%) participants withdrew due to adverse events.

In the double-blind withdrawal phase, withdrawals due to adverse events occurred in 3/43 participants with hydromorphone ER and $0 / 51$ with placebo. An additional participant taking hydromorphone ER and two taking placebo withdrew due to opioid withdrawal symptoms.

\section{Other withdrawals}

In the conversion and titration phase, 15/167 (9\%) participants were withdrawn because of protocol violations and noncompliance. In the double-blind withdrawal phase, 4/43 participants taking hydromorphone ER and 12/51 taking placebo were withdrawn for the same reasons.

\section{Adverse events}

See Appendix 7 for summary of adverse events.

\section{Any adverse event}

During conversion and titration, 95/167 (57\%) participants experienced adverse events. Most were of mild or moderate intensity, and the most commonly reported events were constipation (22 participants) and nausea (15 participants).
During the double-blind withdrawal phase, 21/43 (49\%) participants experienced adverse events with hydromorphone ER and $27 / 51$ (53\%) with placebo. Once again, they were mostly mild or moderate in intensity, and the most commonly reported event with hydromorphone ER was constipation (five participants) and with placebo was opioid withdrawal syndrome (seven participants).

\section{Serious adverse events}

There were no deaths during the study, and serious adverse events were not reported for the neuropathic and non-neuropathic groups separately. In the original study report, which included participants with both neuropathic and non-neuropathic back pain, 6/447 participants evaluated for safety had serious adverse events during the conversion and titration phase, while $6 / 134$ had serious adverse events with hydromorphone ER and 4/134 with placebo in the double-blind withdrawal phase (Hale 2010, see Nalamachu 2014).

\section{DISCUSSION}

\section{Summary of main results}

We found only one post hoc analysis of a study assessing the efficacy of hydromorphone in neuropathic pain to include in this review. The results showed a somewhat larger increase in average pain intensity for placebo than for continuing with hydromorphone $\mathrm{ER}$, but as well as an unusual study design there was an unusual choice of imputation methods for withdrawals (about 50\% of participants). Adverse events occurred in about half of participants with hydromorphone and the most common were constipation and nausea. A similar proportion of participants experienced adverse events with placebo, and in this case the most common was opioid withdrawal syndrome. Most adverse events were mild or moderate in intensity, but a substantial number led to withdrawal, particularly during the conversion and titration phase, despite participants being opioid-tolerant (very low quality and inadequate evidence).

\section{Overall completeness and applicability of evidence}

The amount of evidence we have is small, from one post hoc analysis, and limited to one type of neuropathic pain. While the participants were classified as having chronic low back pain with a definite or probable neuropathic component, the precise nature of the neuropathy was not known and may further limit the generalisability of the results. Participants were opioid-tolerant at screening, and it might be expected that withdrawals would be higher in an unselected population.

There is insufficient evidence to consider how well hydromorphone works even in people with low back pain with a neuropathic component, and these meagre results cannot be generalised to other types of neuropathic pain. We found no information about other routes of administration. Two open-label studies indicated that analgesic efficacy might be possible in some people with neuropathic pain over the longer term. One randomised openlabel comparison between hydromorphone and oxycodone ER formulations in 112 participants had a 52 week follow-up, and showed that reduced pain was maintained over that period (Richarz 2013). One small open cohort (20 participants) also reported that pain decreased in some participants over four weeks (Suzan 2013). 
As best we know, there is no high-quality evidence to support or refute the use of hydromorphone for treating neuropathic pain. This is despite the fact that a UK survey found that weak and strong opioids were used frequently for treating neuropathic pain, either alone or in combination with other drugs (Hall 2013). The lack of high-quality evidence for long term benefit with hydromorphone reflects a similar result with oxycodone, buprenorphine, and other opioids (Gaskell 2014; McNicol 2013; Wiffen 2015). The lack of evidence of efficacy combined with substantial evidence of harm has led to calls for referral to a pain management specialist (ideally with expertise in opioid use) if daily dosing exceeds 80 to $100 \mathrm{mg}$ morphine equivalents, particularly if pain and function are not substantially improved (Franklin 2014).

\section{Quality of the evidence}

The study methods were fundamentally sound, but this was a post hoc analysis, and the number of participants with neuropathic pain was small (Moore 2015). The randomised double-blind withdrawal phase was underpowered, and did not have an outcome related to a level of pain that participants might find acceptable (Moore 2013b). For example, the 'loss of therapeutic response' ('treatment failure' in Hale 2010) is a typical outcome for EERW trials (Moore 2015). Moreover, the one included study used three different imputation methods for withdrawals, depending on reason for withdrawal, and it was not clear how that might affect the conclusions. Taken together, these factors downgraded the evidence for all outcomes to very low quality, which means that further research is very likely to have an important impact on our confidence in our understanding of the effect.

\section{Potential biases in the review process}

We know of no potential biases in the review process. It is unlikely that there is a large body of unpublished evidence showing a large effect from hydromorphone in neuropathic pain.

\section{Agreements and disagreements with other studies or reviews}

This review agrees with previous reviews and Cochrane reviews that there appears to be no body of good clinical studies assessing the efficacy of hydromorphone, at any dose or in any formulation, for neuropathic pain (McNicol 2013). The one study in this review was published after McNicol 2013.

\section{AUTHORS' CONCLUSIONS}

\section{Implications for practice}

\section{For people with neuropathic pain}

There is insufficient evidence to support or refute the suggestion that hydromorphone has any efficacy in any neuropathic pain condition.

\section{For clinicians}

There is insufficient evidence to support or refute the suggestion that hydromorphone has any efficacy in any neuropathic pain condition.

\section{For policy makers}

There is insufficient evidence to support or refute the suggestion that hydromorphone has any efficacy in any neuropathic pain condition. In the absence of any supporting evidence, it should probably not be recommended, except at the discretion of a pain specialist with particular expertise in opioid use.

\section{For funders}

There is insufficient evidence to support or refute the suggestion that hydromorphone has any efficacy in any neuropathic pain condition. In the absence of any supporting evidence, it should probably not be recommended, except at the discretion of a pain specialist with particular expertise in opioid use.

\section{Implications for research}

Large, robust randomised trials with patient-centred outcomes would be required to produce evidence to support or refute efficacy of hydromorphone in neuropathic pain. The necessary design of such trials is well established, but, for opioids in neuropathic pain, the outcomes should be those of at least $30 \%$ and at least $50 \%$ pain intensity reduction over baseline at the end of a trial of 12 weeks' duration in participants continuing on treatment. Withdrawal for any reason should be regarded as treatment failure, and last observation carried forward (LOCF) analysis should not be used. The reason for this is that, in chronic pain, opioids frequently produce withdrawal rates of $50 \%$ or more, meaning that LOCF analysis can overstate treatment efficacy.

\section{ACKNOWLEDGEMENTS}

Institutional support was provided by the Oxford Pain Relief Trust.

The National Institute for Health Research (NIHR) is the largest single funder of the Cochrane Pain, Palliative and Supportive Care Review Group.

Disclaimer: the views and opinions expressed herein are those of the review authors and do not necessarily reflect those of the NIHR, National Health Service (NHS), or the Department of Health.

The protocol followed the agreed template for neuropathic pain, which was developed in collaboration with the Cochrane Musculoskeletal Group and Cochrane Neuromuscular Diseases Group. The editorial process was managed by the Cochrane Pain, Palliative and Supportive Care Group. 


\section{R E F E R E N C E S}

\section{References to studies included in this review}

Nalamachu 2014 \{published data only\}

Hale M, Khan A, Kutch M, Li S. Once-daily OROS hydromorphone ER compared with placebo in opioid-tolerant patients with chronic low back pain. Current Medical Research and Opinion 2010;26(6):1505-18. [DOI: 10.1185/03007995.2010.484723]

Hale ME, Nalamachu SR, Khan A, Kutch M. Effectiveness and gastrointestinal tolerability during conversion and titration with once-daily OROS ${ }^{\circledR}$ hydromorphone extended release in opioid tolerant patients with chronic low back pain. Journal of Pain Research 2013;6:319-29. [DOI: 10.2147/JPR.S39980]

Jamison RN, Edwards RR, Liu X, Ross EL, Michna E, Warnick M, et al. Relationship of negative affect and outcome of an opioid therapy trial among low back pain patients. Pain Practice 2013;13(3):173-81. [DOI: 10.1111/j.1533-2500.2012.00575.x]

* Nalamachu S, Hale M, Khan A. Hydromorphone extended release for neuropathic and non-neuropathic/nociceptive chronic low back pain: a post hoc analysis of data from a randomized, multicenter, double-blind, placebo-controlled clinical trial. Journal of Opioid Management 2014;10(5):311-22. [DOI: 10.5055/jom.2014.0221]

\section{References to studies excluded from this review}

\section{Binsfeld 2010 \{published data only\}}

Binsfeld H, Szczepanski L, Waechter S, Richarz U, Sabatowski R. A randomized study to demonstrate noninferiority of oncedaily OROS $\left({ }^{\circledast}\right)$ hydromorphone with twice-daily sustainedrelease oxycodone for moderate to severe chronic noncancer pain. Pain Practice 2010;10(5):404-15. [DOI: 10.1111/ j.1533-2500.2009.00342.x]

\section{Grosset 2005 \{published data only\}}

Grosset AB, Roberts MS, Woodson ME, Shi M, Swanton RE, Reder RF, et al. Comparative efficacy of oral extended-release hydromorphone and immediate-release hydromorphone in patients with persistent moderate to severe pain: two randomized controlled trials. Journal of Pain and Symptom Management 2005;29(6):584-94. [DOI: 10.1016/ j.jpainsymman.2004.10.008]

\section{Jansen D0-119 \{published data only\}}

Janssen. Jurnista prolonged release tablets, 2012. www.medsafe.govt.nz/profs/datasheet/j/jurnistatab.pdf (accessed 26 November 2015).

\section{Additional references}

\section{Bao 2014}

Bao YJ, Hou W, Kong XK, Yang L, Jones K, Xia J, et al. Hydromorphone for cancer pain. Cochrane Database of Systematic Reviews 2014, Issue 5. [DOI: 10.1002/14651858.CD011108]

\section{Baron 2012}

Baron R, Wasner G, Binder A. Chronic pain: genes, plasticity, and phenotypes. Lancet Neurology 2012;11(1):19-21. [DOI: 10.1016/ S1474-4422(11)70281-2]

\section{Bouhassira 2008}

Bouhassira D, Lantéri-Minet M, Attal N, Laurent B, Touboul C. Prevalence of chronic pain with neuropathic characteristics in the general population. Pain 2008;136(3):380-7. [DOI: 10.1016/ j.pain.2007.08.013]

\section{Calvo 2012}

Calvo M, Dawes JM, Bennett DL. The role of the immune system in the generation of neuropathic pain. Lancet Neurology 2012;11(7):629-42. [DOI: 10.1016/S1474-4422(12)70134-5]

\section{Demant 2014}

Demant DT, Lund K, Vollert J, Maier C, Segerdahl M, Finnerup NB, et al. The effect of oxcarbazepine in peripheral neuropathic pain depends on pain phenotype: a randomised, double-blind, placebo-controlled phenotype-stratified study. Pain 2014;155(11):2263-73. [DOI: 10.1016/j.pain.2014.08.014]

\section{Derry 2012}

Derry S, Moore RA. Topical capsaicin (low concentration) for chronic neuropathic pain in adults. Cochrane Database of Systematic Reviews 2012, Issue 9. [DOI: 10.1002/14651858.CD010111]

\section{Derry 2013}

Derry S, Sven-Rice A, Cole P, Tan T, Moore RA. Topical capsaicin (high concentration) for chronic neuropathic pain in adults. Cochrane Database of Systematic Reviews 2013, Issue 2. [DOI: 10.1002/14651858.CD007393.pub3]

\section{Derry 2014}

Derry S, Wiffen PJ, Moore RA, Quinlan J. Topical lidocaine for neuropathic pain in adults. Cochrane Database of Systematic Reviews 2014, Issue 7. [DOI: 10.1002/14651858.CD010958.pub2]

\section{Dworkin 2008}

Dworkin RH, Turk DC, Wyrwich KW, Beaton D, Cleeland CS, Farrar JT, et al. Interpreting the clinical importance of treatment outcomes in chronic pain clinical trials: IMMPACT recommendations. Journal of Pain 2008;9(2):105-21. [DOI: 10.1016/j.jpain.2007.09.005]

\section{Finnerup 2013}

Finnerup NB, Scholz J, Attal N, Baron R, Haanpää M, Hansson P, et al. Neuropathic pain needs systematic classification. European Journal of Pain 2013;17(7):953-6. [DOI: 10.1002/ j.1532-2149.2012.00282.x]

\section{Finnerup 2015}

Finnerup NB, Attal N, Haroutounian S, McNicol E, Baron R, Dworkin RH, et al. Pharmacotherapy for neuropathic pain in adults: a systematic review and meta-analysis. Lancet Neurology 2015;14(2):162-73. [DOI: 10.1016/S1474-4422(14)70251-0] 


\section{Franklin 2014}

Franklin GM, American Academy of Neurology. Opioids for chronic noncancer pain: a position paper of the American Academy of Neurology. Neurology 2014;83(14):1277-84. [DOI: 10.1212/WNL.0000000000000839]

\section{Gaskell 2014}

Gaskell H, Moore RA, Derry, S, Stannard C. Oxycodone for neuropathic pain and fibromyalgia in adults. Cochrane Database of Systematic Reviews 2014, Issue 6. [DOI: 10.1002/14651858.CD010692.pub2]

\section{GRADEpro GDT 2015 [Computer program]}

McMaster University. GRADEpro Guideline Development Tool. McMaster University, 2015.

\section{Gregory 2013}

Gregory TB. Hydromorphone: evolving to meet the challenges of today's health care environment. Clinical Therapeutics 2013;35(12):2007-27. [DOI: 10.1016/j.clinthera.2013.09.027]

\section{Gustorff 2008}

Gustorff B, Dorner T, Likar R, Grisold W, Lawrence K, Schwarz F, et al. Prevalence of self-reported neuropathic pain and impact on quality of life: a prospective representative survey. Acta Anaesthesiologica Scandinavica 2008;52(1):132-6. [DOI: 10.1111/ j.1399-6576.2007.01486.x]

\section{Hall 2008}

Hall GC, Carroll D, McQuay HJ. Primary care incidence and treatment of four neuropathic pain conditions: a descriptive study, 2002-2005. BMC Family Practice 2008;9:26. [DOI: 10.1186/1471-2296-9-26]

\section{Hall 2013}

Hall GC, Morant SV, Carroll D, Gabriel ZL, McQuay HJ. An observational descriptive study of the epidemiology and treatment of neuropathic pain in a UK general population. BMC Family Practice 2013;14:28. [DOI: 10.1186/1471-2296-14-28]

\section{Helfert 2015}

Helfert SM, Reimer M, Höper J, Baron R. Individualized pharmacological treatment of neuropathic pain. Clinical Pharmacology and Therapeutics 2015;97(2):135-42. [DOI: 10.1002/cpt.19]

\section{Higgins 2011}

Higgins JPT, Altman DG, Sterne JAC. Chapter 8: Assessing risk of bias in included studies. In: Higgins JPT, Green S (editors). Cochrane Handbook for Systematic Reviews of Interventions Version 5.1.0 [updated March 2011]. The Cochrane Collaboration, 2011. Available from www.cochranehandbook.org.

\section{Hoffman 2010}

Hoffman DL, Sadosky A, Dukes EM, Alvir J. How do changes in pain severity levels correspond to changes in health status and function in patients with painful diabetic peripheral neuropathy?. Pain 2010;149(2):194-201. [DOI: 10.1016/ j.pain.2009.09.017]

\section{Jadad 1996}

Jadad AR, Moore RA, Carroll D, Jenkinson C, Reynolds DJ, Gavaghan DJ, et al. Assessing the quality of reports of randomized clinical trials: is blinding necessary?. Controlled Clinical Trials 1996;17(1):1-12. [DOI: 10.1016/0197-2456(95)00134-4]

\section{Jensen 2011}

Jensen TS, Baron R, Haanpää M, Kalso E, Loeser JD, Rice AS, et al. A new definition of neuropathic pain. Pain 2011; Vol. 152, issue 10:2204-5. [DOI: 10.1016/j.pain.2011.06.017]

\section{Kalso 2013}

Kalso E, Aldington DJ, Moore RA. Drugs for neuropathic pain. BMJ 2013;347:f7339. [DOI: 10.1136/bmj.f7339]

\section{Katusic 1991}

Katusic S, Williams DB, Beard CM, Bergstralh EJ, Kurland LT. Epidemiology and clinical features of idiopathic trigeminal neuralgia and glossopharyngeal neuralgia: similarities and differences, Rochester, Minnesota, 1945-1984. Neuroepidemiology 1991;10:276-81. [DOI: 10.1159/000110284]

\section{Koopman 2009}

Koopman JS, Dieleman JP, Huygen FJ, de Mos M, Martin CG, Sturkenboom MC. Incidence of facial pain in the general population. Pain 2009;147(1-3):122-7. [DOI: 10.1016/ j.pain.2009.08.023]

\section{L'Abbé 1987}

L'Abbé KA, Detsky AS, O'Rourke K. Meta-analysis in clinical research. Annals of Internal Medicine 1987;107:224-33.

\section{Lange 2010}

Lange B, Kuperwasser B, Okamoto A, Steup A, Häufel T, Ashworth J, et al. Efficacy and safety of tapentadol prolonged release for chronic osteoarthritis pain and low back pain. Advances in Therapy 2010;27(6):381-99. [DOI: 10.1007/ s12325-010-0036-3]

\section{Lunn 2014}

Lunn MP, Hughes RA, Wiffen PJ. Duloxetine for treating painful neuropathy, chronic pain or fibromyalgia. Cochrane Database of Systematic Reviews 2014, Issue 1. [DOI: 10.1002/14651858.CD007115.pub3]

\section{McNicol 2013}

McNicol ED, Midbari A, Eisenberg E. Opioids for neuropathic pain. Cochrane Database of Systematic Reviews 2013, Issue 8. [DOI: 10.1002/14651858.CD006146.pub2]

\section{McQuay 1998}

McQuay H, Moore R. An Evidence-Based Resource for Pain Relief. Oxford: Oxford University Press, 1998. [ISBN: 0-19-263048-2]

\section{McQuay 2007}

McQuay HJ, Smith LA, Moore RA. Chronic pain. In: Stevens A, Raftery J, Mant J, Simpson S editor(s). Health Care Needs Assessment, 3rd Series. Oxford: Radcliffe Publishing, 2007:519-99. [ISBN: 978-1-84619-063-6] 


\section{Moore 1998}

Moore RA, Gavaghan D, Tramèr MR, Collins SL, McQuay HJ. Size is everything - large amounts of information are needed to overcome random effects in estimating direction and magnitude of treatment effects. Pain 1998;78(3):209-16. [DOI: 10.1016/S0304-3959(98)00140-7]

\section{Moore 2008}

Moore RA, Barden J, Derry S, McQuay HJ. Managing potential publication bias. In: McQuay HJ, Kalso E, Moore RA editor(s). Systematic Reviews in Pain Research: Methodology Refined. Seattle: IASP Press, 2008:15-24. [ISBN: 978-0-931092-69-5]

\section{Moore 2009}

Moore RA, Straube S, Wiffen PJ, Derry S, McQuay HJ. Pregabalin for acute and chronic pain in adults. Cochrane Database of Systematic Reviews 2009, Issue 3. [DOI: 10.1002/14651858.CD007076.pub2]

\section{Moore 2010a}

Moore RA, Eccleston C, Derry S, Wiffen P, Bell RF, Straube S, et al. "Evidence" in chronic pain - establishing best practice in the reporting of systematic reviews. Pain 2010;150(3):386-9. [DOI: 10.1016/j.pain.2010.05.011]

\section{Moore 2010b}

Moore RA, Straube S, Derry S, McQuay HJ. Chronic low back pain analgesic studies - a methodological minefield. Pain 2010;149(3):431-4. [DOI: 10.1016/j.pain.2010.02.032]

\section{Moore 2010c}

Moore RA, Straube S, Paine J, Phillips CJ, Derry S, McQuay HJ. Fibromyalgia: moderate and substantial pain intensity reduction predicts improvement in other outcomes and substantial quality of life gain. Pain 2010;149(2):360-4. [DOI: 10.1016/j.pain.2010.02.039]

\section{Moore 2010d}

Moore RA, Smugar SS, Wang H, Peloso PM, Gammaitoni A. Numbers-needed-to-treat analyses - do timing, dropouts, and outcome matter? Pooled analysis of two randomized, placebocontrolled chronic low back pain trials. Pain 2010;151(3):592-7. [DOI: 10.1016/j.pain.2010.07.013]

\section{Moore 2010e}

Moore RA, Moore OA, Derry S, Peloso PM, Gammaitoni AR, Wang $\mathrm{H}$. Responder analysis for pain relief and numbers needed to treat in a meta-analysis of etoricoxib osteoarthritis trials: bridging a gap between clinical trials and clinical practice. Annals of the Rheumatic Diseases 2010;69(2):374-9. [DOI: 10.1136/ard.2009.107805]

\section{Moore 2011a}

Moore RA, Straube S, Paine J, Derry S, McQuay HJ. Minimum efficacy criteria for comparisons between treatments using individual patient meta-analysis of acute pain trials: examples of etoricoxib, paracetamol, ibuprofen, and ibuprofen/ paracetamol combinations after third molar extraction. Pain 2011;152(5):982-9.

\section{Moore 2011b}

Moore RA, Mhuircheartaigh RJ, Derry S, McQuay HJ. Mean analgesic consumption is inappropriate for testing analgesic efficacy in post-operative pain: analysis and alternative suggestion. European Journal of Anaesthesiology 2011;28(6):427-32. [DOI: 10.1097/EJA.0b013e328343c569]

\section{Moore 2012a}

Moore RA, Derry S, Aldington D, Cole P, Wiffen PJ. Amitriptyline for neuropathic pain and fibromyalgia in adults. Cochrane Database of Systematic Reviews 2012, Issue 12. [DOI: 10.1002/14651858.CD008242.pub2]

\section{Moore 2012b}

Moore RA, Straube S, Eccleston C, Derry S, Aldington D, Wiffen P, et al. Estimate at your peril: imputation methods for patient withdrawal can bias efficacy outcomes in chronic pain trials using responder analyses. Pain 2012;153(2):265-8. [DOI: 10.1016/j.pain.2011.10.004]

\section{Moore 2013a}

Moore A, Derry S, Eccleston C, Kalso E. Expect analgesic failure; pursue analgesic success. BMJ 2013;346:f2690. [DOI: 10.1136/ bmj.f2690]

\section{Moore 2013b}

Moore RA, Straube S, Aldington D. Pain measures and cut-offs - 'no worse than mild pain' as a simple, universal outcome. Anaesthesia 2013;68(4):400-12. [DOI: 10.1111/anae.12148]

\section{Moore 2014a}

Moore RA, Derry S, Taylor RS, Straube S, Phillips CJ. The costs and consequences of adequately managed chronic non-cancer pain and chronic neuropathic pain. Pain Practice 2014;14(1):79-94. [DOI: 10.1111/papr.12050]

\section{Moore 2014b}

Moore RA, Wiffen PJ, Derry S, McQuay HJ. Gabapentin for chronic neuropathic pain and fibromyalgia in adults. Cochrane Database of Systematic Reviews 2014, Issue 4. [DOI: 10.1002/14651858.CD007938.pub3]

\section{Moore 2014c}

Moore RA, Cai N, Skljarevski V, Tölle TR. Duloxetine use in chronic painful conditions - individual patient data responder analysis. European Journal of Pain 2014;18(1):67-75. [DOI: 10.1002/j.1532-2149.2013.00341.x]

\section{Moore 2015}

Moore RA, Wiffen PJ, Eccleston C, Derry S, Baron R, Bell RF, et al. Systematic review of enriched enrolment, randomised withdrawal trial designs in chronic pain: a new framework for design and reporting. Pain 2015;156(8):1382-95. [DOI: 10.1097/ j.pain.0000000000000088]

\section{Murray 2005}

Murray A, Hagen NA. Hydromorphone. Journal of Pain and Symptom Management 2005;29(5):57-66. [DOI: 10.1016/ j.jpainsymman.2005.01.007] 


\section{NICE 2013}

National Institute for Health and Care Excellence (NICE). Neuropathic pain - pharmacological management: the pharmacological management of neuropathic pain in adults in non-specialist settings, 2013. www.nice.org.uk/guidance/cg173 (accessed 19 October 2014).

\section{O'Brien 2010}

O'Brien EM, Staud RM, Hassinger AD, McCulloch RC, Craggs JG, Atchison JW, et al. Patient-centered perspective on treatment outcomes in chronic pain. Pain Medicine 2010;11(1):6-15. [DOI: 10.1111/j.1526-4637.2009.00685]

\section{PaPaS 2012}

Cochrane Pain, Palliative and Supportive Care Group (PaPaS) author and referee guidance. papas.cochrane.org/papasdocuments (accessed 17 November 2015).

\section{Portenoy 2011}

Portenoy RK. Treatment of cancer pain. Lancet 2011;377(9874):2236-47. [DOI: 10.1016/S0140-6736(11)60236-5]

\section{QTFSD 1987}

Quebec Task Force on Spinal Disorders. Scientific approach to the assessment and management of activity-related spinal disorders. A monograph for clinicians. Spine (Phila Pa 1976) 1987;12 (7 Suppl):S1-59. [PUBMED: 2961086]

\section{Rappaport 1994}

Rappaport ZH, Devor M. Trigeminal neuralgia: the role of self-sustaining discharge in the trigeminal ganglion. Pain 1994;56:127-38. [DOI: 10.1016/0304-3959(94)90086-8]

\section{RevMan 2014 [Computer program]}

The Nordic Cochrane Centre, The Cochrane Collaboration. Review Manager (RevMan). Version 5.3. Copenhagen: The Nordic Cochrane Centre, The Cochrane Collaboration, 2014.

\section{Richarz 2013}

Richarz U, Waechter S, Sabatowski R, Szczepanski L, Binsfeld $\mathrm{H}$. Sustained safety and efficacy of once-daily hydromorphone extended-release $\left(\mathrm{OROS}^{\circledR}\right.$ hydromorphone ER) compared with twice-daily oxycodone controlled-release over 52 weeks in patients with moderate to severe chronic noncancer pain. Pain Practice 2013;13(1):30-40. [DOI: 10.1111/ j.1533-2500.2012.00553.x]

\section{Sarhill 2001}

Sarhill N, Walsh D, Nelson KA. Hydromorphone: pharmacology and clinical applications in cancer patients. Supportive Care in Cancer 2001;9(2):84-96. [DOI: 10.1007/s005200000183]

\section{Straube 2008}

Straube S, Derry S, McQuay HJ, Moore RA. Enriched enrolment: definition and effects of enrichment and dose in trials of pregabalin and gabapentin in neuropathic pain. A systematic review. British Journal of Clinical Pharmacology 2008;66(2):266-75. [DOI: 10.1111/j.1365-2125.2008.03200]

\section{Straube 2010}

Straube S, Derry S, Moore RA, Paine J, McQuay HJ. Pregabalin in fibromyalgia - responder analysis from individual patient data. BMC Musculoskeletal Disorders 2010;11:150. [DOI: 10.1186/1471-2474-11-150]

\section{Sultan 2008}

Sultan A, Gaskell H, Derry S, Moore RA. Duloxetine for painful diabetic neuropathy and fibromyalgia pain: systematic review of randomised trials. BMC Neurology 2008;8:29. [DOI: 10.1186/1471-2377-8-9]

\section{Suzan 2013}

Suzan E, Eisenberg E, Treister R, Haddad M, Pud D. A negative correlation between hyperalgesia and analgesia in patients with chronic radicular pain: is hydromorphone therapy a doubleedged sword?. Pain Physician 2013;16(1):65-76.

\section{Torrance 2006}

Torrance N, Smith BH, Bennett MI, Lee AJ. The epidemiology of chronic pain of predominantly neuropathic origin. Results from a general population survey. Journal of Pain 2006;7(4):281-9. [DOI: 10.1016/j.jpain.2005.11.008]

\section{Treede 2008}

Treede RD, Jensen TS, Campbell JN, Cruccu G, Dostrovsky JO, Griffin JW, et al. Neuropathic pain: redefinition and a grading system for clinical and research purposes. Neurology 2008;70(18):1630-5. [DOI: 10.1212/01.wnl.0000282763.29778.59]

\section{Twycross 1994}

Twycross RG. Pain Relief in Advanced Cancer. Singapore: Churchill Livingstone, 1994:279.

\section{Urquhart 1988}

Urquhart ML, Klapp K, White PF. Patient-controlled analgesia: a comparison of intravenous versus subcutaneous hydromorphone. Anesthesiology 1988;69(3):428-32. [PUBMED: 2458059]

\section{van Hecke 2014}

van Hecke O, Austin SK, Khan RA, Smith BH, Torrance N. Neuropathic pain in the general population: a systematic review of epidemiological studies. Pain 2014;155(4):654-62. [DOI: 10.1016/j.pain.2013.11.013]

\section{von Hehn 2012}

von Hehn CA, Baron R, Woolf CJ. Deconstructing the neuropathic pain phenotype to reveal neural mechanisms. Neuron 2012;73(4):638-52. [DOI: 10.1016/j.neuron.2012.02.008]

\section{Vos 2012}

Vos T, Flaxman AD, Naghavi M, Lozano R, Michaud C, Ezzati M, et al. Years lived with disability (YLDs) for 1160 sequelae of 289 diseases and injuries 1990-2010: a systematic analysis for the Global Burden of Disease Study 2010. Lancet 2012;380(9859):2163-96. [DOI: 10.1016/S0140-6736(12)61729-2]

\section{Wiffen 2013}

Wiffen PJ, Derry S, Moore RA, Aldington D, Cole P, Rice ASC, et al. Antiepileptic drugs for neuropathic pain and 
fibromyalgia - an overview of Cochrane reviews. Cochrane Database of Systematic Reviews 2013, Issue 11. [DOI: 10.1002/14651858.CD010567.pub2]

\section{Wiffen 2015}

Wiffen PJ, Derry S, Moore RA, Stannard C, Aldington D, Cole $\mathrm{P}$, et al. Buprenorphine for neuropathic pain in adults. Cochrane Database of Systematic Reviews 2015, Issue 9. [DOI: 10.1002/14651858.CD011603.pub2]

\section{CHARACTERISTICS OF STUDIES}

Characteristics of included studies [ordered by study ID]

\section{References to other published versions of this review Quigley 2013}

Quigley C. Hydromorphone for acute and chronic pain. Cochrane Database of Systematic Reviews 2013, Issue 10. [DOI: 10.1002/14651858.CD003447.pub2]

* Indicates the major publication for the study

Nalamachu 2014

\begin{tabular}{ll}
\hline Methods & Multicentre, double-blind, placebo-controlled study with open-label conversion and titration phase (2 \\
to 4 weeks), and randomised, double-blind, parallel-group withdrawal phase (12 weeks) for 'responder- \\
S' (enriched enrolment, randomised withdrawal study). Responders took 12 to 64 mg hydromorphone \\
ER daily, with dose unchanged for $\geq 7$ consecutive days, mean $\mathrm{PI} \leq 4 / 10$, required $\leq 2$ tablets of rescue \\
medication daily, had no intolerable AEs, believed study medication had helped their pain
\end{tabular}

Interventions

Titration phase:

Starting dose of hydromorphone ER orally equivalent to $75 \%$ equianalgesic dose of previous total daily opioid dose. Maximum dose $64 \mathrm{mg}$ daily

Randomised withdrawal phase:

Hydromorphone ER orally, $n=134$ (43 NP, 91 non-NP)

Placebo orally (tapered down over 2 weeks), $n=133$ (51 NP, 83 non-NP)

\begin{tabular}{ll}
\hline Outcomes & Responders during conversion and titration \\
& Mean change in weekly PI over withdrawal phase, and both phases (scale 0 to 10) \\
& PGA (1 to 5) \\
& Use of rescue medication \\
AEs & Oxford Quality Score: R2, DB2, W1. Total $=5 / 5$ \\
\hline Notes &
\end{tabular}


Nalamachu 2014 (Continued)

Risk of bias

\begin{tabular}{|c|c|c|}
\hline Bias & Authors' judgement & Support for judgement \\
\hline $\begin{array}{l}\text { Random sequence genera- } \\
\text { tion (selection bias) }\end{array}$ & Low risk & "computer-generated randomization schedule" \\
\hline $\begin{array}{l}\text { Allocation concealment } \\
\text { (selection bias) }\end{array}$ & Low risk & $\begin{array}{l}\text { "automated assignment of treatment groups to randomization numbers", "in- } \\
\text { teractive voice response system" }\end{array}$ \\
\hline $\begin{array}{l}\text { Blinding of participants } \\
\text { and personnel (perfor- } \\
\text { mance bias) } \\
\text { All outcomes }\end{array}$ & Low risk & "matching placebo" \\
\hline $\begin{array}{l}\text { Blinding of outcome as- } \\
\text { sessment (detection bias) } \\
\text { All outcomes }\end{array}$ & Low risk & "matching placebo" \\
\hline $\begin{array}{l}\text { Incomplete outcome data } \\
\text { (attrition bias) } \\
\text { All outcomes }\end{array}$ & Unclear risk & $\begin{array}{l}\text { Imputation for withdrawals: BOCF for opioid withdrawal symptoms; SOCF for } \\
\text { AEs; LOCF for lack of efficacy }\end{array}$ \\
\hline Size & High risk & $<50$ participants per treatment arm (43 to 51 ) \\
\hline
\end{tabular}

AE: adverse event; BOCF: baseline observation carried forward; CRPS: Chronic Regional Pain Syndrome; DB: double-blind; ER: extended release; F: female; LBP: low back pain; LOCF: last observation carried forward; M: male; N: number of participants in study; n: number of participants in treatment arm; NP: neuropathic pain; PGA: Patient Global Assessment; PI: pain intensity; R: randomised; SD: standard deviation; SOCF: screening observation carried forward; W: withdrawals.

Characteristics of excluded studies [ordered by study ID]

\begin{tabular}{ll}
\hline Study & Reason for exclusion \\
\hline Binsfeld 2010 & Open-label, mixed pain conditions (results not reported separately for neuropathic pain) \\
\hline Grosset 2005 & $\begin{array}{l}\text { Mixed pain conditions (results not reported separately for neuropathic pain), double-blind treat- } \\
\text { ment period only } 3 \text { to } 7 \text { days }\end{array}$ \\
\hline Jansen DO-119 & Non-malignant or cancer pain, randomised treatment lasted only 7 days \\
\hline
\end{tabular}

\section{A P PE N D I C E S}

\section{Appendix 1. Methodological considerations for chronic pain}

There have been several changes in how the efficacy of conventional and unconventional treatments is assessed in chronic painful conditions. The outcomes are now better defined, particularly with new criteria for what constitutes moderate or substantial benefit (Dworkin 2008); older trials may only report participants with 'any improvement'. Newer trials tend to be larger, avoiding problems from the random play of chance. Newer trials also tend to be of longer duration, up to 12 weeks, and longer trials provide a more rigorous and valid assessment of efficacy in chronic conditions. New standards have evolved for assessing efficacy in neuropathic pain, and we are now applying stricter criteria for the inclusion of trials and assessment of outcomes, and are more aware of problems that may affect our overall assessment. To summarise some of the recent insights that must be considered in this new review. 
1. Pain results tend to have a U-shaped distribution rather than a bell-shaped distribution. This is true in acute pain (Moore 2011a; Moore 2011b), back pain (Moore 2010d), and arthritis (Moore 2010e), as well as in fibromyalgia (Straube 2010); in all cases, average results usually describe the experience of almost no-one in the trial. Data expressed as averages are potentially misleading, unless they can be proven to be suitable.

2. As a consequence, we have to depend on dichotomous results (the individual either has or does not have the outcome) usually from pain changes or patient global assessments. The Initiative on Methods, Measurement, and Pain Assessment in Clinical Trials (IMMPACT) group has helped with their definitions of minimal, moderate, and substantial improvement (Dworkin 2008). In arthritis, trials of less than 12 weeks' duration, and especially those shorter than eight weeks, overestimate the effect of treatment (Moore 2010d); the effect is particularly strong for less effective analgesics, and this may also be relevant in neuropathic-type pain.

3. The proportion of people with at least moderate benefit can be small, even with an effective medicine, falling from $60 \%$ with an effective medicine in arthritis to 30\% in fibromyalgia (Moore 2009; Moore 2010d; Moore 2013a; Moore 2014c; Straube 2008; Sultan 2008). One Cochrane review of pregabalin in neuropathic pain and fibromyalgia demonstrated different response rates for different types of chronic pain (higher in diabetic neuropathy and postherpetic neuralgia and lower in central pain and fibromyalgia) (Moore 2009). This indicates that different neuropathic pain conditions should be treated separately from one another, and that pooling should not be done unless there are good reasons for doing so.

4. Individual patient analyses indicate that people who get good pain relief (moderate or better) have major benefits in many other outcomes, affecting quality of life in a significant way (Moore 2010c; Moore 2014a).

5. Imputation methods such as last observation carried forward (LOCF), used when participants withdraw from clinical trials, can overstate drug efficacy especially when adverse event withdrawals with drug are greater than those with placebo (Moore 2012b).

\section{Appendix 2. Search strategy for CENTRAL (via CRSO)}

1. MESH DESCRIPTOR neuralgia EXPLODE ALL TREES (610)

2. MESH DESCRIPTOR peripheral nervous system diseases EXPLODE ALL TREES (2588)

3. MESH DESCRIPTOR somatosensory disorders EXPLODE ALL TREES (709)

4. ((pain ${ }^{\star}$ or discomfort $\left.{ }^{\star}\right)$ adj10 (central or complex or nerv* or neuralg* or neuropath*)):TI,AB,KY (3258)

5. ((neur ${ }^{\star}$ or nerv $\left.{ }^{\star}\right)$ adj6 (compress ${ }^{\star}$ or damag $\left.\left.{ }^{\star}\right)\right): \mathrm{TI}, \mathrm{AB}, \mathrm{KY}(629)$

6. 1 OR 2 OR 3 OR 4 OR 5 (6300)

7. MESH DESCRIPTOR hydromorphone EXPLODE ALL TREES (170)

8. (hydromorphone or Dilaudid or Hydal or Dimorphone or Sophidone LP or Hydrostat or Hydromorfan or Hydromorphan or Hymorphan or Laudicon or Opidol or Palladone or Hydromorph Contin):TI,AB,KY (404)

9. 7 OR 8 (404)

10.6 AND 9 (22)

\section{Appendix 3. Search strategy for MEDLINE via Ovid}

1. $\exp$ NEURALGIA/ (15064)

2. $\exp$ PERIPHERAL NERVOUS SYSTEM DISEASES/ (124097)

3. exp SOMATOSENSORY DISORDERS/ (17884)

4. ((pain* or discomfort $\left.{ }^{\star}\right)$ adj10 (central or complex or nerv* or neuralg* or neuropath*)).mp. (42955)

5. ((neur ${ }^{\star}$ or nerv $\left.{ }^{\star}\right)$ adj6 (compress ${ }^{\star}$ or damag $\left.\left.^{\star}\right)\right) \cdot m p$. (52046)

6. 1 or 2 or 3 or 4 or 5 (199368)

7. Hydromorphone/ (1077)

8. (hydromorphone or Dilaudid or Hydal or Dimorphone or Sophidone LP or Hydrostat or Hydromorfan or Hydromorphan or Hymorphan or Laudicon or Opidol or Palladone or Hydromorph Contin).mp. (1592)

9. 7 or 8 (1592)

10. randomized controlled trial.pt. (416204)

11.randomized.ab. (308128)

12. placebo.ab. (159228)

13.drug therapy.fs. (1858104)

14.randomly.ab. (218251)

15.trial.ab. (320573)

16.groups.ab. (1374115)

17.10 or 11 or 12 or 13 or 14 or 15 or 16 (3473482)

18.6 and 9 and $17(74)$ 


\section{Appendix 4. Search strategy for EMBASE}

1. exp NEURALGIA/ (81187)

2. $\operatorname{exp~PERIPHERAL~NERVOUS~SYSTEM~DISEASES/~(55028)~}$

3. exp SOMATOSENSORY DISORDERS/ (71741)

4. ((pain ${ }^{\star}$ or discomfort ${ }^{\star}$ ) adj10 (central or complex or nerv ${ }^{\star}$ or neuralg* or neuropath*)).mp. (80398)

5. ((neur ${ }^{\star}$ or nerv $\left.{ }^{\star}\right)$ adj6 (compress ${ }^{\star}$ or damag $\left.\left.{ }^{\star}\right)\right) \cdot m p .(73605)$

6. 1 or 2 or 3 or 4 or $5(293248)$

7. Hydromorphone/ (6990)

8. (hydromorphone or Dilaudid or Hydal or Dimorphone or Sophidone LP or Hydrostat or Hydromorfan or Hydromorphan or Hymorphan or Laudicon or Opidol or Palladone or Hydromorph Contin).mp. (7250)

9. 7 or $8(7250)$

10.crossover-procedure/ (45155)

11.double-blind procedure/ (127324)

12.randomized controlled trial/ (391259)

13. (random ${ }^{\star}$ or factorial ${ }^{\star}$ or crossover ${ }^{\star}$ or cross over $^{\star}$ or cross-over ${ }^{\star}$ or placebo* or (doubl ${ }^{\star}$ adj blind ${ }^{\star}$ ) or assign* or allocat $^{\star}$ ).tw. (1397488)

14.10 or 11 or 12 or $13(1481030)$

15.6 and 9 and 14 (153)

\section{Appendix 5. GRADE: criteria for assigning grade of evidence}

The GRADE system uses the following criteria for assigning grade of evidence (GRADEpro GDT 2015).

1. High = further research is very unlikely to change our confidence in the estimate of effect.

2. Moderate $=$ further research is likely to have an important impact on our confidence in the estimate of effect and may change the estimate.

3. Low = further research is very likely to have an important impact on our confidence in the estimate of effect and is likely to change the estimate.

4. Very low = any estimate of effect is very uncertain.

We decrease grade if we find:

1. a serious (-1) or very serious (-2) limitation to study quality;

2. important inconsistency $(-1)$;

3. some (-1) or major (-2) uncertainty about directness;

4. imprecise or sparse data $(-1)$;

5. a high probability of reporting bias $(-1)$.

Appendix 6. Summary of outcomes: efficacy

\begin{tabular}{|c|c|c|c|}
\hline Study & Treatment & Pain outcome & Other efficacy outcome \\
\hline $\begin{array}{l}\text { Nalamachu } \\
2014\end{array}$ & $\begin{array}{l}\text { Titration: HM ER } \\
12 \text { to } 64 \text { mg daily } \\
\text { Randomised } \\
\text { withdrawal: } \\
\text { (1) HM ER (titrated } \\
\text { dose) } \\
\text { (2) Placebo (2- } \\
\text { week down titra- } \\
\text { tion) }\end{array}$ & $\begin{array}{l}\text { No dichotomous data for NP subgroup } \\
\text { Titration: } \\
\text { 94/167 completed } \\
\text { Mean PI reduced from } 6.4 \text { (SD 2.0) to } 3.2 \text { (SD } \\
\text { 1.1) (scale } 0 \text { - 10) } \\
\text { Mean PGA reduced from } 3.7 \text { (SD 0.9) to } 2.6 \\
\text { (SD 0.8) (scale } 1 \text { - 5) } \\
\text { Randomised withdrawal: } \\
\text { Mean PI change (scale } 0 \text { - 10) } \\
\text { HM ER } 0.6\end{array}$ & $\begin{array}{l}\text { Titration: } \\
\text { Mean RMDQ scores reduced from } 14 \text { (SD 10) to } \\
10 \text { (SD 6.0) } \\
\text { Randomised withdrawal: } \\
\text { Mean RMDQ change } \\
\text { HM ER } 1.1 \\
\text { Placebo } 3.2 \text { (P value = 0.027) } \\
\text { Use of rescue medication } \\
\text { HM ER } 1.5 \text { tablets/day, mean daily dose } 7.4 \text { (SD } \\
7.1 \text { ) mg }\end{array}$ \\
\hline
\end{tabular}


(Continued)

\author{
Placebo 1.4 $(\mathrm{P}$ value $=0.025)$ \\ Placebo 1.8 tablets/day, mean daily dose 9.1 \\ Mean PGA change (scale 1 - 5) \\ (7.2) $\mathrm{mg}$ \\ HM ER 0.3 \\ Placebo 0.6 (not significant)
}

HM ER: hydromorphone (extended release); NP: neuropathic pain; PGA: Patient Global Assessment; PI: pain intensity; RMDQ: RolandMorris Disability Questionnaire; SD: standard deviation.

Appendix 7. Summary of outcomes: adverse events and withdrawals

\begin{tabular}{|c|c|c|c|c|}
\hline Study & Treatment & Adverse events & Serious AEs & Withdrawals \\
\hline $\begin{array}{l}\text { Nala- } \\
\text { machu } \\
2014\end{array}$ & $\begin{array}{l}\text { Titration: HM } \\
\text { ER } 12 \text { to } 64 \mathrm{mg} \\
\text { daily } \\
\text { Randomised } \\
\text { withdrawal: } \\
\text { (1) HM ER } \\
\text { (titrated dose) } \\
\text { (2) Placebo (2- } \\
\text { week down } \\
\text { titration) }\end{array}$ & $\begin{array}{l}\text { Titration: } \\
\text { Any AE 95/167 } \\
\text { (most mild or moderate) } \\
\text { Treatment-related } 70 / 167 \\
\text { Most common were constipation } \\
\text { (22 participants) and nausea (15 } \\
\text { participants) } \\
\text { Randomised withdrawal: } \\
\text { Any AE } \\
\text { HM ER } 21 / 43 \\
\text { Placebo } 27 / 51 \\
\text { (most mild or moderate) } \\
\text { Most common with HM was con- } \\
\text { stipation (5 participants), with } \\
\text { placebo was opioid withdrawal } \\
\text { syndrome ( } 7 \text { participants) }\end{array}$ & $\begin{array}{l}\text { Serious AEs reported on- } \\
\text { ly for all CLBP participants } \\
\text { (Hale 2010) } \\
\text { Titration: } 6 / 447 \\
\text { Randomised withdrawal: } \\
\text { HM ER 6/134 } \\
\text { Placebo 4/134 } \\
\text { (Serious AEs may have all } \\
\text { occurred in participants } \\
\text { with non-NP CLBP) }\end{array}$ & $\begin{array}{l}\text { All cause } 73 / 167 \\
\text { LoE } 27 / 167 \\
\text { AE } 20 / 167 \\
\text { Protocol violation/non-compli- } \\
\text { ance } 15 / 167 \\
\text { Randomised withdrawal: } \\
\text { All cause } \\
\text { HM ER } 21 / 43 \\
\text { Placebo } 30 / 51 \\
\text { LoE } \\
\text { HM ER } 8 / 43 \\
\text { Placebo } 9 / 51 \\
\text { AE } \\
\text { HM ER } 3 / 43 \\
\text { Placebo } 0 / 51 \\
\text { Protocol violation/non-compli- } \\
\text { ance } \\
\text { HM ER } 4 / 43 \\
\text { Placebo } 12 / 51\end{array}$ \\
\hline
\end{tabular}

AE: adverse event; CLBP: chronic low back pain; HM ER: hydromorphone (extended release); LoE: lack of efficacy; NP: neuropathic pain.

WHAT'S NEW

\begin{tabular}{lll}
\hline Date & Event & Description \\
\hline 24 January 2018 & Review declared as stable & See Published notes \\
\hline
\end{tabular}




\section{H I S T O R Y}

Protocol first published: Issue 3, 2015

Review first published: Issue 5, 2016

\begin{tabular}{lll}
\hline Date & Event & Description \\
\hline 13 June 2016 & Amended & Minor change to wording in Declarations of interest, for clarity. \\
\hline
\end{tabular}

\section{CONTRIBUTIONS OF AUTHORS}

SD and RAM wrote the protocol.

SD, PW, and RAM searched for and selected studies for inclusion, and carried out data extraction.

All review authors were involved in writing the full review.

PW will be responsible for any updates required.

\section{DECLARATIONS OF INTEREST}

CS: none known; CS is a specialist pain physician and manages patients with neuropathic pain

HG: none known; HG is an Associate Specialist in Clinical Geratology.

SD: none known.

DA is a specialist pain physician and manages patients with neuropathic pain. He has received lecture fees from Grünenthal (2013, 2014, 2015) and Pfizer (2013, 2016).

PC is a specialist pain physician and manages patients with neuropathic pain. He has received support from Pfizer (2013) and Boston Scientific (2014) for travel and accommodation at a scientific meeting.

TC: none known.

RK has consulted for Grünenthal (2014-15) and MundiPharma Research (2015), and received lecture fees from Grünenthal (2013-14), and Pfizer Ltd (2013-14).

PW: none known.

RAM has received grant support from RB relating to individual patient level analyses of trial data on ibuprofen in acute pain and the effects of food on drug absorption of analgesics (2013), and from Grünenthal relating to individual patient level analyses of trial data regarding tapentadol in osteoarthritis and back pain (2015). He has received honoraria for attending boards with Menarini concerning methods of analgesic trial design (2014), with Novartis (2014) about the design of network meta-analyses, and RB on understanding pharmacokinetics of drug uptake (2015).

\section{SOURCES OF SUPPORT}

\section{Internal sources}

- Oxford Pain Relief Trust, UK.

General institutional support

\section{External sources}

- The National Institute for Health Research (NIHR), UK.

NIHR Cochrane Programme Grant: 13/89/29 - Addressing the unmet need of chronic pain: providing the evidence for treatments of pain 


\section{DIFFERENCES BETWEEN PROTOCOLAND REVIEW}

The protocol included both complex regional pain syndrome (CRPS) I and CRPS II as a diagnosis of neuropathic pain. We have now removed CRPS I because it is no longer considered to be neuropathic pain. There were no studies in CRPS I.

In the 'Summary of findings' table, we included the outcome 'lack of efficacy withdrawal in randomised double-blind phase', since this may be a relevant indicator of efficacy for this enriched enrolment, randomised withdrawal study design.

\section{NOTES}

A restricted search in January 2018 did not identify any potentially relevant studies likely to change the conclusions. The authors and editors are confident that further research will not change the conclusions. Therefore, this review has now been stabilised following discussion with the authors and editors. If appropriate, we will update the review if new evidence likely to change the conclusions is published, or if standards change substantially which necessitate major revisions.

\section{N DEX TERMS}

\section{Medical Subject Headings (MeSH)}

Analgesics, Opioid [ ${ }^{\star}$ therapeutic use]; Chronic Pain [ ${ }^{\star}$ drug therapy]; Hydromorphone [ ${ }^{\star}$ therapeutic use]; Neuralgia [ ${ }^{\star} d r u g$ therapy]; Randomized Controlled Trials as Topic

\section{MeSH check words}

Adult; Humans 